\title{
Atrial Natriuretic Peptide in Patent Ductus Arteriosus
}

\author{
STURE ANDERSSON, ILKKA TIKKANEN, ERKKI PESONEN, OLLI MERETOJA, \\ MARKKU HYNYNEN, AND FREJ FYHRQUIST \\ Department of Medical Chemistry, University of Helsinki [S.A.]; Children's Hospital [S.A., E.P., O.M.], and \\ Department of Anaesthesia [O.M., M.H.], University Central Hospital, Helsinki, and Unit of Clinical Physiology, \\ Minerva Foundation Institute for Medical Research [I.T., F.F.], Kauniainen, Finland
}

\begin{abstract}
Plasma concentrations of atrial natriuretic peptide (ANP) were measured in nine infants (age 4 days9 months) before and after closure of patent ductus arteriosus. Initially all patients had marked distention of the left atrium as indicated by a left atrium to aortic root ratio $\geq 1.3$ on echocardiography. After closure of the ductus, operative in six and pharmacological in three patients, left atrial size normalized (left atrium to aortic root ratio < 1.3 ) in all patients, except in one treated surgically. Before closure the plasma concentration of ANP was 86-2224 pg/ $\mathrm{ml}$ and after closure $44-1400 \mathrm{pg} / \mathrm{ml}$. There was a significant correlation between the size of left atrium and plasma concentration of ANP $(r=0.56 ; p=0.01)$. Our results suggest that in infants with patent ductus arteriosus the left atrium is the main source of ANP. The secretory rate of ANP decreases immediately after restoring left atrial size by closure of the ductus. (Pediatr Res 21: 396-398, 1987)
\end{abstract}

\section{Abbreviations}

ANP, atrial natriuretic peptide

LA/Ao, left atrium to aortic root

Mammalian atria contain peptides with potent diuretic, natriuretic, and vasorelaxing properties $(1-5)$. These peptides are released in response to volume distention of the atria $(6,7)$. Plasma concentration of ANP is also increased in adult patients with congestive heart failure and supraventricular tachycardia $(8,9)$ and in children with different congenital heart and pulmonary diseases (10).

The ductus arteriosus closes postnatally within $12 \mathrm{~h}$ in $50 \%$ of full-term newborns and the closure is usually completed on the 3rd postnatal day (11). A delayed closure of the ductus increases the pulmonary flow, which leads to distention of the left atrium during systole when the mitral valve is closed preventing the pulmonary venous return to the left ventricle (12). The size of the left atrium can be estimated by echocardiography (Fig. 1) (12). Incomplete closure of the ductus is frequently seen in prematures and in newborns with respiratory distress syndrome (11). Therapeutical closure of the ductus, by indomethacin or by operation, may be needed because of symptoms due to the increased pulmonary circulation through the open ductus (13).

Received June 25, 1986; accepted December 2, 1986.

Correspondence Sture Andersson, Department of Medical Chemistry, Siltavuorenpenger $10, \mathrm{SF} 00170$ Helsinki, Finland.

Supported by Finska Läkaresällskapet, the Finnish Foundation for Cardiovascular Research, the Paavo Nurmi's Foundation, the Sigrid Juselius Foundation, the Nordisk Insulinfond, and by the Finnish Academy.
The aim of the present work was to study the effect of distention of the left atrium on the plasma concentration of ANP in infants with patent ductus arteriosus and in response to restoration of the normal atrial size by closure of the ductus.

\section{PATIENTS AND METHODS}

Patients. Nine patients underwent therapeutic closure of patent ductus arteriosus as summarized in Table 1 . The presence of a patent ductus arteriosus was diagnosed clinically, radiologically, and echocardiographically. The diagnosis was confirmed peroperatively in the patients who underwent surgery and by decrease in atrial size in the newborns treated with indomethacin. None of the patients had signs of other cardiac diseases. The six neonates all had some degree of respiratory distress and they were cared for in a respirator at the time of the study.

The ductus was closed surgically in six patients and intravenous administration of indomethacin was instituted in three patients. Patient 9 was anaesthetized with thiopentone, fentanyl, pancuronium, nitrous oxide, and enflurane. Isotonic glucose was infused at constant rate $(2.3 \mathrm{ml} / \mathrm{kg} / \mathrm{h})$ throughout the operation. The external diameter of the ductus of this patient measured at the operation was $8 \mathrm{~mm}$.

Echocardiography. All echocardiographic examinations were performed by the same cardiologist before and after the closure of the ductus. The size of the left atrium was estimated by twodimensional echocardiography as measured at endsystole just before the opening of the mitral valve. Dilatation of the left atrium was determined as a LA/Ao ratio of 1.3 or more (Fig. 1) (12).

Blood samples and assay method. Blood samples $(0.5-0.8 \mathrm{ml})$ for determination of plasma ANP concentrations were taken immediately after the echocardiographic examinations. Samples were drawn from peripheral veins or through umbilical artery catheters. The same route was used for pre- and posttherapeutic sampling with the exception of patient 9. From this patient peripheral venous blood was collected pre- and postoperatively after the echocardiographic examinations, while blood from a radial artery catheter inserted for peroperative monitoring was sampled during the operation and until $24 \mathrm{~h}$ postoperatively. The blood samples were collected in ice cold $\mathrm{K}_{2}$ EDTA tubes which were immediately centrifuged and the plasma $(0.2-0.4 \mathrm{ml})$ was stored at $-20^{\circ} \mathrm{C}$.

Radioimmunoassay of ANP was carried out as described previously (14). Linear regression was applied for statistical evaluation of the data. The study protocol was approved by the ethical committee of the Children's Hospital, University of Helsinki.

\section{RESULTS}

All patients had initially marked dilatation of the left atrium as determined by a LA/Ao ratio of more than 1.3. The six 
youngest patients, i.e. numbers 1 to 6 , whose ages at the first examination were $1 \mathrm{wk}$ or less, all had LA/Ao ratios of more than 1.4 (mean 1.67). Accordingly the highest ANP concentrations (mean $1507 \mathrm{pg} / \mathrm{ml}$ ) were observed in this group. The three older patients, i.e. numbers 7,8 , and 9 , had initially both lower $\mathrm{LA} / \mathrm{Ao}$ ratios (mean 1.33) and ANP concentrations (mean 217 $\mathrm{pg} / \mathrm{ml}$ ) (Table 1 and Fig. 2).

After closure of the ductus the ANP level decreased in all patients and the LA/Ao ratio was normalized in all patients except in patient 7 . This patient also showed one of the smallest changes of ANP concentration. There was a statistically significant correlation $(r=0.56 ; p=0.01)$ between the size of the left atrium measured by the LA/Ao ratio and the plasma concentration of ANP (Fig. 2).

Operation of patient 9. The plasma level of ANP was not affected by anaesthesia or thoracotomy (Fig. 3). After ligation of the ductus the plasma concentration of ANP decreased instantly. Ten minutes after the ligation the concentration of ANP was 158 $\mathrm{pg} / \mathrm{ml}$ which is $36 \%$ of the value $(440 \mathrm{pg} / \mathrm{ml})$ immediately before the ligation.

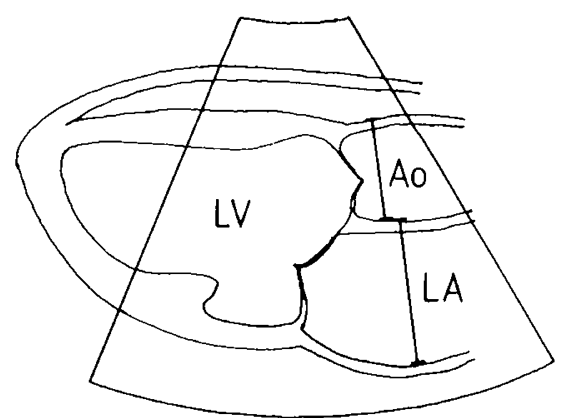

Fig. 1. Echocardiographic measurement of the LA/Ao ratio. $L A$, left atrium; $A O$, aorta; $L V$, left ventricle.

\section{DISCUSSION}

In our investigation the initial ANP concentrations were higher in all patients than those measured in healthy adults $(3,8)$. The degree of distention of the left atrium correlated with plasma concentrations of ANP. The highest LA/Ao ratios were observed in the prematures and in this group both the posttherapeutic decrease in size of the left atrium and in plasma level of ANP were also most marked. It is possible that the great compliance of the atrium of the newborn, and especially of the premature,

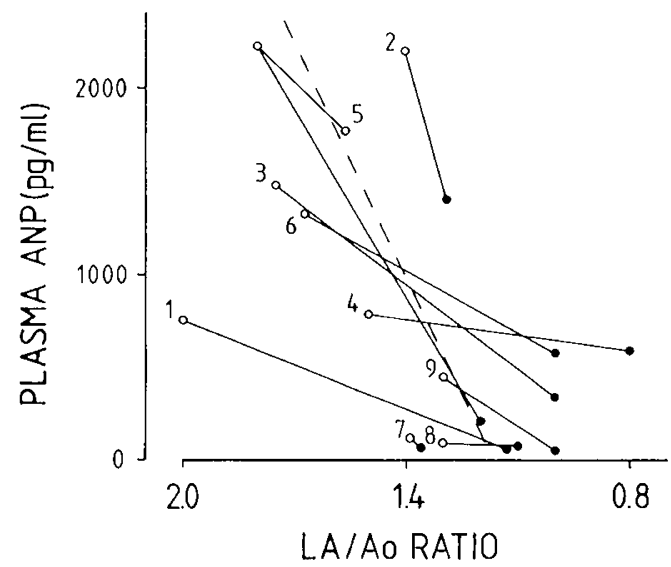

Fig. 2. Dependance of plasma ANP concentration on the left atrial size. Plasma ANP concentration is given as $\mathrm{pg} / \mathrm{ml}$ and left atrial size as LA/Ao ratio. Open circles represent pretherapeutic and closed circles posttherapeutic measurements. Note that patient 5 was examined twice before closure of the ductus. The correlation $(r=0.56 ; p=0.01)$ between plasma ANP concentration and LA/Ao ratio is indicated by the broken line $(y=-1030.8 \pm 1334.8 \times X)$. Numbers of the patients are as in Table 1 .

Table 1. Patient data; measurement of $L A /$ Ao ratio and plasma ANP

\begin{tabular}{|c|c|c|c|c|c|c|c|}
\hline \multirow[b]{2}{*}{ Patient } & \multirow{2}{*}{$\begin{array}{l}\text { Sex, gestational } \\
\text { age, birth wt } \\
\text { length }(\mathrm{g} / \mathrm{cm}) \\
\text { Apgar score } 1 / \\
5 \mathrm{~min} \\
\end{array}$} & \multicolumn{3}{|c|}{ Initial examination } & \multicolumn{3}{|c|}{ Posttherapeutic examination } \\
\hline & & Age & LA/Ao ratio & $\begin{array}{l}\text { Plasma ANP } \\
(\mathrm{pg} / \mathrm{m} \mathrm{l})\end{array}$ & Age & $\begin{array}{l}\text { LA/Ao } \\
\text { Ratio }\end{array}$ & $\begin{array}{c}\text { Plasma ANP } \\
(\mathrm{pg} / \mathrm{ml})\end{array}$ \\
\hline 1 & $\begin{array}{c}\mathrm{M}, 25+0 \mathrm{wk} \\
760 / 32,4 / 5\end{array}$ & 7 day & 2.00 & 756 & 9 day $(2 \text { day })^{*}$ & 1.13 & 52 \\
\hline 2 & $\begin{array}{l}F, 24+6 w k \\
760 / 33,3 / 6\end{array}$ & 5 day & 1.40 & 2200 & 8 day ( 0 day) & 1.29 & 1400 \\
\hline 3 & $\begin{array}{l}\mathrm{M}, 31+4 \mathrm{wk} \\
\quad 1790 / 44,8 / \\
9\end{array}$ & 7 day & 1.75 & 1480 & 9 day (2 day) & 1.00 & 340 \\
\hline 4 & $\begin{array}{l}\mathrm{M}, 28+6 \mathrm{wk} \\
1320 / 41,2 / \\
8\end{array}$ & 6 day & 1.50 & 784 & 9 day ( 2 day) & 0.80 & 584 \\
\hline \multirow[t]{2}{*}{5} & $\mathrm{M}, 31+0 \mathrm{wk}$ & 4 day & 1.56 & 1774 & & & \\
\hline & $\begin{array}{l}1300 / 39,8 / \\
9\end{array}$ & 6 dayt & 1.80 & 2224 & 9 day ( 2 day) & 1.20 & 204 \\
\hline 6 & $\begin{array}{r}\mathrm{F}, 29+5 \mathrm{wk} \\
560 / 32,1 / 7\end{array}$ & 4 day & 1.67 & 1330 & 7 day ( 3 day) & 1.00 & 574 \\
\hline 7 & $\begin{array}{l}\mathrm{M}, 35+4 \mathrm{wk} \\
1930 / 45,8 / \\
8\end{array}$ & $\begin{array}{l}2.5 \\
\text { mo }\end{array}$ & 1.39 & 114 & $\begin{array}{l}2.5 \mathrm{mo}(6 \\
\text { day })\end{array}$ & 1.36 & 64 \\
\hline 8 & $\begin{array}{l}\mathrm{F}, 29+4 \mathrm{wk} \\
1555 / 38,7 / \\
8\end{array}$ & $3 \mathrm{wk}$ & 1.30 & 86 & 3 wk (2 day) & 1.10 & 72 \\
\hline 9 & $\begin{array}{l}\mathrm{F}, 38+0 \mathrm{wk} \\
\quad 3130 / 51,9 / \\
10\end{array}$ & $9 \mathrm{mo}$ & 1.31 & 450 & 9 mo (4 day) & 1.00 & 44 \\
\hline
\end{tabular}

* Time after therapy (indomethacin in patient 2, 3, and 4; operative in all the others).

$\uparrow$ Patient 5 was examined twice before the therapy. 


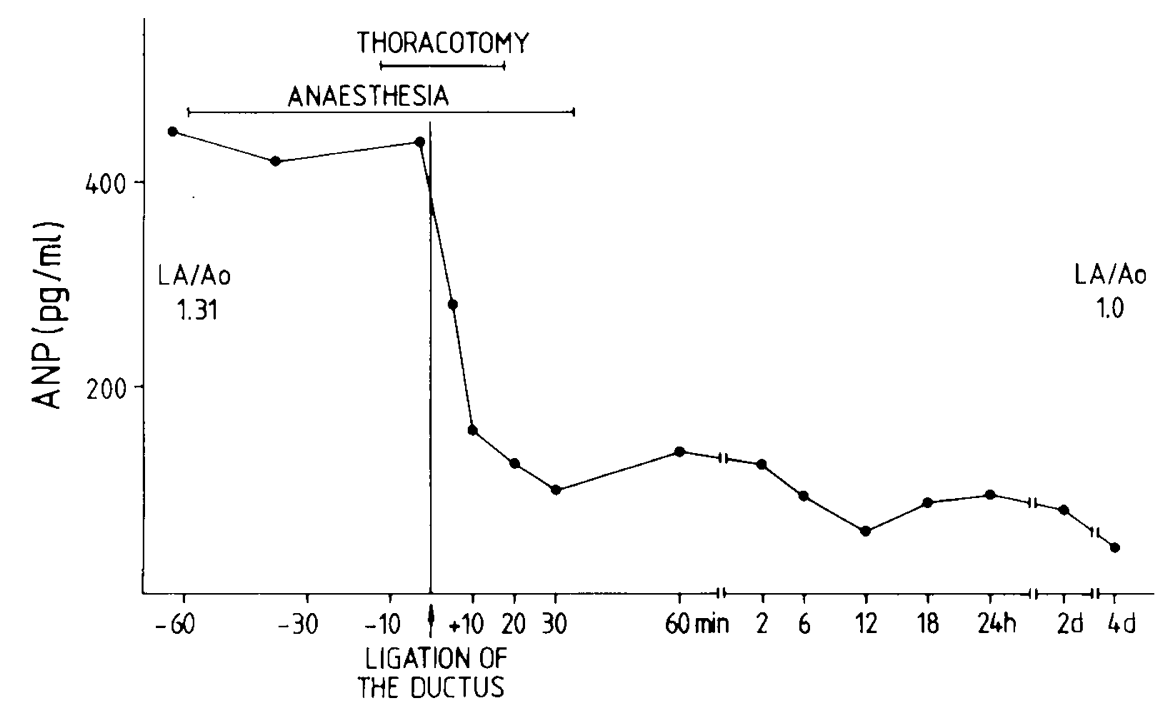

Fig. 3. Operative closure of the ductus of patient number 9. The ligation of the ductus, indicated by arrow, represent the zero time. Plasma ANP concentration is given as in Figure 2. The half-life of ANP is 4.0 min as estimated on the concentrations measured immediately before and 5 and 10 min after the ligation.

causes prominent strain on the atrial wall in the presence of a patent ductus arteriosus. Another factor responsible for the high ANP concentrations in the neonates may be the acute postnatal onset of the dilation of the atrium compared to the more chronic situation in the older children. In newborns there is a physiological increase of plasma ANP concentrations to a mean of 227 $\mathrm{pg} / \mathrm{ml} \mathrm{2-4}$ days postnatally (17). After the 4th day of life the normal values are $53-159 \mathrm{pg} / \mathrm{ml}(17)$. All neonates of our study were older than 4 days at the first examination and their initial ANP concentrations were $756-2224 \mathrm{pg} / \mathrm{ml}$. Thus, developmental changes of ANP levels have negligible effects on our results.

Increased levels of circulating ANP have been measured in experimental animals with increased stretch of the left (15) or the right (7) atrium. Because the patent ductus arteriosus does not affect the size of the right atrium (13) the present results indicate that the distended left atrium is the most important source of ANP in infants with patent ductus arteriosus. This possibility is further confirmed by the instant decrease of ANP concentration after operative closure of the ductus in patient 9 . The estimated half-life of ANP of $4 \mathrm{~min}$ in this patient also corroborates the short half-life of ANP in man as has been determined previously (16). This result is in accordance with the observation of the rapid decrease in ANP concentration after cessation of supraventricular tachycardia in adult patients (9). The differences in ANP levels measured after closure of the ductus may be caused by factors acting on the right atrium. There may also still be some strain on the left atrial wall, the left atrial size being at the upper limit of the normal at the time of the measurement. Moreover, because of the wide normal variation of the LA/Ao ratio, the obtained numerical values only semiquantitatively indicate the size of the left atrium of one individual, whereas in a group of patients the increased left atrial size, measured as a high mean LA/Ao ratio, reflects left atrial strain. However, small variations of the stretch of the left atrial wall that may affect the release of ANP are not measurable by noninvasive techniques.

In conclusion, infants with distended left atrium due to patent ductus arteriosus have markedly elevated plasma concentrations of ANP. The size of the left atrium is significantly correlated to the level of ANP. In this condition, high plasma ANP may be considered a marker of mainly left atrial wall strain. Reduction of plasma ANP may serve as an indicator of successful therapeutic closure of patent ductus arteriosus in infants. In view of the potent vasorelaxing properties of ANP (3), possible hemodynamic consequences of exaggerated ANP release in this condition should be considered and further explored.
Acknowledgments. The authors thank Mrs. Marja Ylhäinen and Mr. Ahmet Pekiner for skillful laboratory assistance.

\section{REFERENCES}

1. Editorial 1984 Atrial natriuretic peptides. Lancet 2:328-329

2. Cantin M, Genest $\mathbf{J} 1985$ The heart and the atrial natriuretic factor. Endocrinol Rev 6:107-127

3. Ballerman BJ, Brenner BM 1985 Biologically active peptides. J Clin Invest 75:2041-2048

4. Flier JS, Laragh JH, Underhill CH 1985 Atrial natriuretic hormone, the reninaldosterone axis, and blood pressure-electrolyte homeostasis. N Engl J Med 312:1330-1340

5. Needleman P, Adams SP, Sole BR, Currie MG, Geller DM, Michener ML, Saper CB, Schwartz D, Standaert DG 1985 Atriopeptins as cardiac hormones. Hypertension 7:469-482

6. Lang RE, Thoelken H, Ganten D, Luft FC, Rusoaho H, Unger T 1985 Atrial natriuretic factor-a circulating hormone stimulated by volume loading. Nature 314:264-266

7. Katsube N, Schwartz C, Needleman P 1985 Release of atriopeptin in the rat by vasoconstrictors or water immersion correlates with changes in the right atrial pressures. Biochem Biophys Res Commun 133:937-944

8. Tikkanen I Fyhrquist F, Metsärinne K, Leidenius R 1985 Plasma atrial natriuretic peptide in cardiac disease and during infusion in healthy volunteers. Lancet 2:66-69

9. Tikkanen I, Metsärinne K, Fyhrquist F 1985 Atrial natriuretic peptide in paroxysmal supraventricular tachycardia. Lancet 2:40-41

10. Lang RE, Unger T, Ganten D, Weil J, Bidlingmaier F, Dohlemann D 1985 Atrial natriuretic peptide concentrations in plasma of children with congenital heart and pulmonary diseases. Br Med J 291:1241

11. Daniels O, Hopman JCW, Stoelinga CBA, Busch HJ, Peer PGM 1981 A combined Doppler echocardiographic investigation in premature infants with and without respiratory distress syndrome. In: Rijsterborg $\mathrm{H}$ (ed) Echocardiology. Nijhoff Publishers, The Hague, pp 409-415

12. Silverman NH, Lewis AB, Heymann MA, Rudolph AM 1974 Echocardiographic assessment of ductus arterious shunt in premature infants. Circulation 50:821-825

13. Heymann MA 1983 Patent ductus arteriosus. In: Adams FH, Emmanouilides GC (eds) Moss' Heart Disease in Infants, Children and Adolescents. Williams $\&$ Wilkins, Baltimore, pp 158-171

14. Gutowska J, Thibault G, Januszewitcz P, Cantin M, Genest J 1984 Direct radioimmunoassay of atrial natriuretic factor. Biochem Biophys Res Commun 122:593-601

15. Ledsome JR, Wilson N, Courneya CA, Rankin AJ 1985 Release of atrial natriuretic peptide by atrial distension. Can J Physiol Pharmacol 63:739_ 742

16. Yandle TG, Crozier I, Espiner EA, Ikram H, Nicholls MG 1985 Production, plasma levels, and clearance of atrial natriuretic peptide in man. Hypertension 7:838(abstr)

17. Weil J, Bidlingmaier F, Döhlemann C, Kuhnle U, Strom T, Hollicek A, Lang RE 1986 Comparison of plasma atrial natriuretic peptide levels in healthy children from birth to adolescence and in children with cardiac diseases. Pediatr Res 20:1328-1331 